\title{
THE STRUGGLE OF SULTAN BABULLAH IN EXPELLING PORTUGUESE FROM NORTH MALUKU
}

\author{
Johan Setiawan and Dyah Kumalasari \\ Departemen Penndidikan Sejarah, Fakultas Ilmu Sosial, UNY \\ johansetiawan.2017@student.uny.ac.iddandyah_kumalasari@uny.ac.id
}

Abstract: $\quad$ This research was aimed at knowing Sultan Babullah's struggle in expelling Portuguese from North Maluku in the year 1570-1783. This research employed history method with the following steps (1) heuristic (2) source critic (3) interpretation (4) historiography. The research results were: (1) The murder of Sultan Khairun that was done by Antonio Pimental ordered by Diego Lopez de Mesquita was the cause of resistance arising as well as eviction that was done by Sultan Babullah to Portuguese, (2) Babullah struggle started when he was inducted as Sultan of Ternate in 28th of February 1570. During his induction, he swore to take revenge on his father's death. Babullah flamed Soya-soya war or land liberation war. Portuguese's posts were destroyed. Portuguese's defense fortresses were taken down one by one except Gamlamo Fortress, (3) The final struggle of Babullah was when Gamlamo Fortress as Portuguese's defense fortress was encircled for five years from 1570-1575 until Portuguese surrendered and was evicted from North Maluku.

Abstrak: Penelitian ini bertujuan untuk mengetahui bagaimanakah Perjuangan Sultan Babullah dalam mengusir Portugis dari Maluku Utara tahun 1570-1783. Penelitian ini menggunakan metode sejarah dengan langkah sebagai berikut: (1) heuristik, (2) kritik sumber, (3) interpretasi, (4) historiografi. Hasil penelitian yang diperoleh yaitu: (1) Pembunuhan Sultan Khairun yang dilakukan oleh Antonio Pimental atas perintah Diego Lopez de Mesquita menjadi penyebab bangkitnya perlawanan serta pengusiran yang dilakukan Sultan Babullah terhadap Portugis, (2) Perjuangan Babullah dimulai ketika dilantik menjadi Sultan Ternate pada 28 Februari 1570. Saat pelantikannya ia bersumpah menuntut balas atas kematian ayahnya. Babullah mengobarkan Perang Soya-soya atau perang pembebasan negeri. Pos-pos Portugis di berbagai tempat di hancurkan. Benteng-benteng pertahanan Portugis satu per satu dapat direbut, hanya tersisa Benteng Gamlamo, (3) Akhir Perjuangan Babullah ketika Benteng Gamlamo sebagai benteng pertahanan terakhir Portugis dikepung selama lima tahun 1570-1575, hingga Portugis menyerah dan terusir dari Maluku Utara.

Kata Kunci: perjuangan, Sultan Babullah, Portugis

\section{PENDAHULUAN}

Before the arrival of European nations such as Portuguese, Spanish, Dutch, and English in the Archipelago, there had been trading activities that were done by local merchants with Arab, Gujarat, Persia, and China in the Archipelago. Besides trading, they also performed a marriage with local people and spread Islam religion resulted in Islamization. After Moslem communities were formed and became bigger, a harbor town located at the coastal area was then formed.

The arrival of European to the Archipelago was aimed to find regions that produce spices. Maluku as one of the centers of spices' producers such as clove, nutmeg, and mace that made Maluku a meeting point of the merchants' activities from Asian or European nations.

The sailor ship of European to the Archipelago was backgrounded by the fall of Constantinople City as the center of spices into Usmani Turkey's hand that happened in the year 1453. This made the European nation urged to find spices producers regions. The development of science and technology such as shipping, navigation, and compass triggered ocean exploration that was done by Europeans. This made European came to the Archipelago.
At that time, Portuguese and Spanish were two rivals in finding spices producers regions and disagreement often occurred between them. Therefore based on the initiative of Pope Alexsander VI in 1494, they met in negotiation table and made an agreement about authority distribution for them known as Tordesillas Agreement mentioning that Portuguese had the right to use a sailing route to the east and Spanish to the west was reached (Hamid, 2013, p.111). It can be inferred that America's region and around belonged to Spanish and Asia belonged to Portuguese.

As written in the history, Portuguese was the first European nation that came to the Archipelago's region with economic, adventure and religion motives (Zuhdi, 2002, p.1). Portuguese arrived at the Archipelago and succeeded to take over Melaka's Sultanate in 1511 under the leadership of Alfonso d'Alberquerque.

After that, Alfonso Alberquerque ordered Antonio De Abreu and Francesco Serrao to find spices archipelago. They made it to Maluku archipelago exactly at Ternate Sultanate in the year 1512. At that time, Maluku was classified into two big sultanates, namely Ternate and Tidore Sultanate (Hamid, 2013, p.140). Portuguese's arrival in Maluku coincided with political instability between Ternate and Tidore Sultanate. 
The arrival of Portuguese at Ternate Sultanate was welcomed by Sultan Bayan Sirullah and Francesco Serrao was assigned to be a privy counselor. It made Tidore's Sultanate felt threatened due to a close relationship between Portuguese and Ternate. Tidore might be attacked at any time by Ternate with the assistance of Portuguese because the two Sultanates were in conflict.

Maluku's region such as Jailolo, Tidore, Bacan, Makian, and Ternate was rich of spices sources that made Portuguese urged to monopolize and to take over. The good relationship between Ternate and Tidore Sultanates time by time became a feud. This was due to Portuguese's ambitious demeanor who turned the back upon Ternate Sultanate's leader.

Unfriendly demeanor was showed by Portuguese to Ternate Sultanate's side, the Portuguese even killed Sultan Khairun that created anger for Ternate people. The successor of Sultan Khairun who was his son named Babullah was inducted as sultan in the year 1570 and swore to take revenge on his father's death and promised to expel Portuguese from the region of North Maluku.

With jihad battle that was announced to the whole people, so the battle happened and the power in Maluku was united to fight Portuguese and was able to defeat it. This victory finally made Portuguese be expelled from North Maluku and become the first victory for local people in defeating European in the Archipelago.

Based on the background above, the problem formulation in this research was how was the struggle of Sultan Babullah in expelling Portuguese from North Maluku in the year 15701783 ? The aim of this research was to find out how was the struggle of Sultan Babullah in expelling Portuguese from North Maluku in the year 1570-1783

\section{RESEARCH METHOD}

Method that was used in this research was historical research method, because this research took the object from events that happened in the past. According to Notosusanto (1984, p.11) steps in historical research are: (1) Heuristic is a process to find historical sources. The researcher try to find and gather historical sources needed. Heuristic activity is also focused to find literary books written by historian. (2) Critic is to investigate whether the historical trail is real or fake. In this research the researcher tried to find out and to prove the authenticity of the sources that the researcher got, after that the researcher compared and picked from some books and sources that the researcher believed that the news and the sources could become guidelines in writing this research. (3) Interpretation after getting the needed facts so that we have to string up the facts become makes sense as a whole. (4) Historiography is a writing activity in form of research result report that uses citing skill from book with available sources. This arrangement and writing use critical thinking and analysis so that it becomes systematic history.

\section{DISCUSSION \\ 1. General Relationship Image between Ternate Sultanate and Portuguese}

At East Indonesia region, Ternate was the biggest sultanate and the widest in terms of territory (Amal, 2010, p.55). Ternate was one of spices producers became a very busy place visited by merchants from the country's remote spot until from foreign countries.

During the administration of Sultan Bayanullah 15001522 Portuguese arrived in Maluku. The arrival of Portuguese in Ternate was welcomed by Sultan Bayanullah. But warm welcome from the people and from the ruler was not taken by Portuguese and it started to show disrespectful manner.

The close relationship between Portuguese and Ternate was benefited by Portuguese to barge in a local matter. It was done so that their position became stronger in dominating political situation all over the sultanate region. Especially when Sultan Bayanullah passed away in 1522, political conspiracy started to emerge in the royal family circle about who had the right to sit on the throne.

Portuguese started to barges in the throne's replacement and placed Tabariji as sultan in the year 1533-1534. However, since he always refused Portuguese's will, he was put down from his throne by Portuguese and was exiled to Goa, India (Ricklefs, 2007, p.35) until passed away and replaced by Sultan Khairun.

Sultan Khairun governed from 1534 to 1570 , was an open leader and gave chances to other religions to spread their religion in the sultanate region that he lead, During the administration of Sultan Khairun, Jesuit or Christianity mission got many facilitations from Sultan Khairun. They got some facilities, such as transportation, in form of Joanga along with paddlers who took them to Moro.

Whereas this kind of aid was usually made through the governor because the whole logistic mission was sent from Melaka. If the logistic ship had not yet arrived, the empire usually gave emergency aids such as rice, fish, and many others. But the manner shown by Khairun showed his kindness to allow Jesuit mission to do Christianization mission in local people whether or not they are already Moslem (Amal, 2010, p.181).

Jesuit mission had succeeded to spread Christian Religion in both local people circle and sultanate family circle. In sultanate official circle people who moved from Islam to Christian were Dona Catarina, Done Isabella and her husband, Pati, Sangaji, Don Manuel Tabariji. Some Botato of Ternate Kingdom, such as Sangaji Moti, Gamkonora dan Kolano Sabi were let by Sultan Khairun to move to Christian Religion (Amal, 2009, p.182).

The relationship between Ternate Sultanate between the governance of Sultan Khairun and Portuguese was well. When Henrique de Sa became Portuguese Governor in Maluku, Henrique de Sa as someone who knew Maluku and 
Ternate's sultanate family from up close tried to create a better relationship with Khairun.

Therefore, during the reign of Henrique de Sa, Khairun could cooperate well. This relationship happened until the reign of Governor Diego Lopez de Mesquita as the replacement of De Mendosa who had unfriendly manner and showed unlikelihood to Khairun (Amal, 2009, p.189).

\section{The Cause of Portuguese Eviction from North Maluku in Year 1570-1583}

For Mesquita as long as Khairun showed an unwillingness to bend down to Portuguese dominance, so Khairun was believed as an obstruction to Portuguese. Mesquite had an initial plan to kill Sultan Khairun.

His unlikelihood to Sultan Khairun was showed when the incident in Moro region that was said be hindered by Moslems, by burning and killing local Christian. Mesquita accused Khairun as the mastermind of the attack. So Mesquita sent his fleets under the command of Marrama to go to Moro to protect Christian people there.

Khairun had a hunch that he had been slandered by Mesquita. Khairun wanted to investigate that incident by sending his son Babulllah to Moro to find out the truth. When he arrived in Moro, the reality was that Marramaque provoked the people of Moro to admit Portuguese's dominance. This made Khairun got angry because Moro was Ternate's territory and sent his troops to attack Portuguese's troops in Moro. Portuguese became worried because the number of troops sent by Khairun was big in number and raided Portuguese's troops who had a smaller number in Moro.

Therefore, Portuguese Governor Mesquita made reconciliation with Sultan Khairun and then they made a promise with each other using their own holy books to take care of freedom in Maluku. This reconciliation was seen as lost for Portuguese by Mesquita and added with some Christian settlements such as in Sugala, Pune, and Mamuya left their belief and moved from Christian. It made Mesquita arrange a scenario to destroy Sultan Khairun from his dominance.

In the night time, Sultan Khairun was invited by Mesquita to celebrate a reconcilement party inside Gamlamo Fortress. Khairun came to fulfill that invitation without a tight guard. Sultan Khairun bravely went into the fortress, but since that moment he never returned to his palace again. It was because Mesquita ordered his own nephew Antonio Pimental to stab Khairun with a keris (Amal, 2010, p.82).

Sultan Khairun who was tolerant in terms of religion and gave many facilities to Jesuit Mission was betrayed by Portuguese and was killed despicably. Mesquita even ordered to cut off the head of Sultan Khairun and to embed it at the edge of a spear so that it can be watched by Ternate people. This made the struggle of Sultan Babullah as the successor of Ternate Sultanate became increasing in expelling Portuguese from the region of North Maluku.

This was because previously war between Ternate Sultanate and Portuguese was in fact due to defend the sultanate territory. Therefore, during the reign of Sultan Babullah the 1570-1583, it was already raised as eviction form Ternate, North Maluku (Leirissa, 1999, p.59).

\section{The Path of Babullah's Struggle in Expelling Portuguese from North Maluku 1570-1583}

Sultan Babullah was born in Ternate on February 10th, 1528 with the full name of Babullah Datu Syah. The eldest son of Sultan Khairun with his queen consort named Boki Tanjung, the eldest daughter of Sultan Bacan Alauddin I. When he was young, Babullah sat on some strategic positions.

His latest position before becoming sultan was Ocean Kapita. This was the highest military position in the Ternate Sultanate structure. Because this high position, he was often involved in a number of conquest mission especially in Maluku, North and Central Sulawesi region.

His knowledge in Islamic Religion was never been doubted because the palaces mubaligs have guided Babullah to master the form of government and military besides knowledge about religion. Babullah was well prepared to hold the throne of Ternate Sultanate and was been well educated mentally as the successor of his father as Sultan. It was hoped that Babullah could implement pure task to lead jihad war against Europe arrogance.

Since his father's death who was killed despicably by Portuguese, Babullah officially inducted as the Sultan of Ternate in February 28th, 1570 (Subroto, 2016, p.37). In his acceptance speech after being inducted as the sultan of Ternate, he swore to take revenge on his father's death and also swore to fight until the last Portuguese left his nation (Suryo, 2001, p.126).

After officially became Sultan, Babullah issued some policies such as all control upon Ternate Sultanate would be handled autonomically by Babullah and would be helped by the sultanate formal authority. The facilities that had been given by Khairun to Jesuit Mission were stopped. Even Babullah ordered his troops to hunt Portuguese wherever and to kill them (Amal, 2010, p.83).

Sultan Babullah demanded that the killer of his father Governor Diego Lopez de Mesquita to be put to Portuguese court in Ternate and if he was proven guilty, he had to be punished severely. This demand was delivered by Babullah to Portuguese King in Lisbon or young king in Goa. However, Portuguese was difficult to fulfill this demand, because there war convention that was valid for governor, that he could not be punished for the deed he did during his reigning period (Amal, 2009, p.197).

The unfulfilled demand of Babullah made the relationship between them became sharper. Babullah issued an announcement that was the follow-up of the refusal from Portuguese to sent Mesquita to court, such as: First, prohibit all foreign ships to enter Maluku's waters. Second, forbid conversion of Moslems to Christian Religion and canceled all the facilities that were given by Khairun to Jesuit Mission during this time. Third, command private Portuguese, military 
personnel, Jesuit Mission and Local Christian people in Moro and Bacan to gather in Ternate (Amal, 2009, p.199).

The banning of the foreign ship especially Portuguese's in Maluku, by Babullah, was meant to disconnect the relationship between Portuguese in Maluku and the outside world. So that Portuguese people who had been staying in Maluku would face difficulties to ask for personnel, weapon, and ammunition. That, in the end, made them be over a barrel with Babulllah's troops. The banning of conversion was done so that the spread of Christian religion was not done to Moslems. Sultan Babullah ordered that all Portuguese people and Christians to gather in Ternate so that they were placed in one place.

Soon, Sultan Babullah designed war strategy to destroy Portuguese people who were in the whole Maluku Archipelago. Sultan fired Soya-soya War or land liberation war by preparing 2000 war fleet along with more than 120.000 soldiers.

To strengthen his position and to find an ally, Sultan Babullah married the sister of Sultan Iskandar Sani from Tidore. From this marriage, Tidore was united through a marriage relationship. The Kings in Maluku forgot rivalry between them and they were united in one command under Sultan Babullah and Ternate's banner. Sultan Babullah had some great war commanders such as Kapita Kapalaya, Kapita Kalakinka, Kapita Rubuhongi, and Kapita Kolasineo

Sultan Babullah sent Kapita Kolasineo to lead his fleet to Ambon and around. This fleet firstly arrived in Buru, a region with Moslems who were loyal to Sultan Ternate and were always ready with the hassle and battle power. From Baru, Kolasineo went to Residi and Kombelo in Hoamoal's archipelago and then went to Hitu in Ambon to add more ship and personnel. After that, this fleet started to fight Portuguese people in Ambon who were inside fortress to take cover (Amal, 2010, p.83-84).

Christians in Ambon became panicked and anxious, worried about being slaughtered by the Islamic army of Ternate. However, once the Islamic army arrived, they firmly stated that Ambonese Christians would be forgiven and would not be forced to convert to Islam, as long as they acknowledged submitting to the authority of Sultan Baabullah. The one who is chased and must be killed is the Portuguese-Christian invaders as a cruel traitor.

When Ambon was already under control, the troops of Sultan Babullah moved to two directions: one warrior troops were sent to encircle the fortress and Portuguese's defense basis in Seram and another warrior troops were sent to destroy Christian's fortresses in Bacan. Sultan Tidore supported Babullah's troops by helping him in battle (Djaelani, 1999, p.4). Until the year 1570, Portuguese's posts in some places were destroyed. Portuguese's defense fortresses were taken one by one by Babullah. Such as Fort Tolocce Fortress, Santo Pedro Fortress until Santo Pedro, and only left Gamlamo Fortress as the last Portuguese's defense fortress in Maluku.

Portuguese faced lost and victory was gained by Babullah's troops. It made the last Portuguese's troops, missionaries, and Christian people went to cover inside Gamlamo Fortress. Sultan Babullah gave two options to them: First go back to the previous religion (conversion) and went back under the support of sultanate, or second stay in current Christian Religion and get a status as prisoners and go inside Gamlamo Fortress and blend with the Portuguese (Amal, 2009, p.203).

\section{The End of Babullah's Struggle in Expelling Portuguese from North Maluku 1570-1575}

Gamlamo Fortress was the last defense fortress that was possessed by Portuguese. Gamlamo Fort was established by the Portuguese in 1521 (Hanna, 1983, p.3). Portuguese faced a number of lost, they could only take cover and hold out in Gamlamo Fortress from the attack of Babullah's troops. To end this war, Gamlamo Fortress was ordered to be encircled by Babullah started from the year 1570 to 1575 .

The siege took place, the Portuguese troops in Gamlamo fort requested help from troops from Malacca. But at the same time Malacca was under attack by the Aceh Sultanate in 15731574, making Portuguese troops in Malacca and Portuguese Young Kings in Goa, India also busy helping Portuguese troops maintain their position in Malacca, so they could not send aid to Portuguese troops in Maluku who were besieged in Gamlamo fortress (Hayati, 2000).

Gamlamo Fortress started to be encircled by Sultan Babullah with his troops for five years (Ricklefs, 2007, p.35), this fortress was the witness of the death of Sultan Khairun that was done by Portuguese. The people of Ternate became united under the command of Sultan Babullah, encircled the fortress, even Babullah's action who had greatness in leading obtained support from many parties. Resistance also emerged from the people of Tidore and Bacan against the Portuguese. So that it was correct to state that at that time the whole Maluku moved together to fight Portuguese (Djakariyah. 2014, p.120)

The encirclement of Gamlamo Fortress that was done Babullah by closing all access, both roads, and food distribution is limited in certain amounts (Utomo, 2016, p.157). This siege made the residents of the fortress started to be contaminated by diseases and be stricken by hunger. At the last year of encirclement, only 400 from 900 residents of the fortress were left and were able to stay alive. Including Antonio Pimental who is Mesquita's cousin who stabbed Khairun was dead since he was contaminated by thiamine deficiency when the encirclement inside Gamlamo Fortress.

The people survived by eating snake, rat, dog, cat, even house lizard. Those who were sick consumed potions from leaves and plant's roots. It made Portuguese, Missionaries and local Christian people's moral extremely decreased (Amal, 2010, p.84-85).

To end this battle, on 24 December 1575 Sultan Babullah sent his uncle Kaicil Toro, to meet the latest Portuguese Governor, Nuno Pareira de Lacerda, inside Gamlamo Fortress. De Lacerda was in unhealthy condition and was very skinny, due to lack of nutrition. Kaicil Toro delivered messages from Babullah that consisted of three numbers, such as First The residents of the fortress to surrender without any condition in 24 hours of time, started from 12:00 in the afternoon. 
Second, the whole residents of the fortress would be deported to Ambon or Melaka after the surrender. Third, if they did not want to surrender at 6:00 in tomorrow morning 1000 of Babullah's troops would attack (Amal, 2009, p.208).

The latest Portuguese Governor named De Lacerda finally accepted those conditions offered by Sultan Babullah. Exactly at 28 December 1575 De Lacerda went out of the fortress in a weak condition and was followed by his 400 troops. They got security assurance from Sultan Babullah and were under guard when they were moved to Ambon and Malaka.

They were the last Portuguese people who were kicked out of North Maluku under the administration of Sultan Babullah in the year 1575. It made Sultan Babullah the first sultan who succeeded to defeat European people. And the deeds he did in giving protection to Portuguese people who surrendered, showed his action as a knightly person.

During his administration that happened until 1583, The Ternate Sultanate expanded and achieving its glory (Vlekke, 2008, p.114), in the north side until Mindano, in the south until Bima, in the east until West Irian, and in the west until Makassar. Its territory consisted of 72 islands (Kartodirdjo, 1987, p.118).

This was supported by a declaration by Valentijn as a researcher from the Netherland, he elaborated that at least there were 72 regions or kingdoms that were under the influence of Ternate Sultanate. This was how Sultan Babullah got his epithet as "The Ruler of 2 lands" (Reid, 1993, p.38). Also during his administration, the number of Christian people in North Maluku decreased drastically. Many Christian people who were converted to Islam by Sultan Babullah (Aritonang, 2004, p.39).

Despite being very powerful, and having expelled Portuguese. Sultan Babullah kept in touch with the Europeans who came to Ternate to trade, they remained embraced and welcomed to cooperate, but were denied the special privileges that were once granted by the sultanate ternate to the Portuguese nation Sultan of Babullah died in 1583 which brought the peak of Ternate.

\section{SIMPULAN}

The cause of Portuguese's Eviction from North Maluku 1570-1583. It happened because Portuguese wanted to monopolize the trading of spices and barged in local business of Ternate Sultanate. Whereas the main factor was the murder of Sultan Khairun inside Gamlamo Fortress that was done by Antonio Pimental based on the order from Diego Lopez de Mesquita in the year 1570. This incident raised resistance together with eviction that was done by Sultan Babullah as the successor of the Ternate Sultanate's throne to Portuguese from the region of North Maluku. Second Babullah's struggle started when he was inducted as the Sultan of Ternate in 28th of February 1570. In his position acceptance speech, he swore to take revenge on the death of his father and to struggle until the last Portuguese left his land. Sultan Babullah demanded that the killer of his father Mesquita to be sent to Portuguese's court in Ternate and this demand was delivered to Portuguese
King, but it was refused. So that after Sultan Babullah planned war strategy, to destroy Portuguese people that were in Maluku's Archipelago. Sultan fired the Soya-soya war or land liberation war by preparing 2000 battle fleets along with more than 120.000 troops. Babullah sent Kapita Kolasineo to lead the fleet and attack Portuguese people, Portuguese's posts in some places were destroyed. Portuguese's defense fortresses were taken down one by one until the rest was only Gamlamo Fortress. Third The end of Babullah's struggle was when Gamlamo Fortress as the last defense fortress that was owned by Portuguese was encircled by Sultan Babullah for five years. The encirclement of Gamlamo Fortress made the residents of the fortress were contaminated by diseases and were stricken by hunger. In the last year of encirclement, only 400 from 500 residents of the fortress were left and were able to survive. Including Antonio Pimental, the cousin of Mesquita who stabbed Khairun was dead inside Gamlamo Fortress. To end this encirclement, in 24th of December 1575 Sultan Babullah sent an order that the residents of the fortress surrender without any condition in 24 hours. The latest Governor of Portuguese finally surrendered.

\section{REFERENSI}

Amal, M. A. (2009). Portugis \& Spanyol di Maluku. Jakarta: Komunitas Bambu dengan Pemerintahan Kota Ternate.

Amal, M. A. (2010). Kepulauan Rempah-rempah: Perjalanan Sejarah Maluku Utara 1250-1950. Jakarta: KPG (Kepustakaan Populer Gramedia).

Aritonang, J. S. (2004). Sejarah Perjumpaan Kristen dan Islam di Indonesia. Jakarta: BPK Gunung Mulia.

Djaelani, A. Q. (1999). Perang Sabil Versus Perang Salib, Ummat Islam Melawan Penjajahan Kristen Portugis dan Belanda. Jakarta: Yayasan Pengkajian Islam Madinah AlMunawwarah.

Djakariyah. (2014). Sejarah Indonesia II. Yogyakarta: Penerbit Ombak Dua

Hamid, A. R. (2013). Sejarah Maritim Indonesia. Yogyakarta: Penerbit Ombak.

Hanna, W. A. (1983). Kepulauan Banda, Kolonialisme dan akibatnya. Jakarta: Gramedia.

Hayati dkk. (2000). Peranan Ratu Kalinyamat di jepara pada Abad XVI. Jakarta: Proyek Peningkatan Kesadaran Sejarah Nasional Direktorat Sejarah dan Nilai Tradisional Direktorat Jenderal Kebudayaan Departemen Pendidikan Nasional.

Kartodirdjo, S. (1988). Pengantar Sejarah Indonesia Baru 15001900. Jakarta: Gramedia.

Leirissa, R. Z. dkk. (1999). Ternate Sebagai Badar Jalur Sutra. Jakarta: CV. Ilham Bangun Karya.

Notosusanto, N. (1984). Masalah Penelitian Sejarah Kontemporer: Suatu Pengalaman. Jakarta: Yayasan Penerbit Universitas Indonesia.

Reid, A. (1993). Southeast Asia in the Early Modern Era. Amerika Serikat: Publisher Cornell University Press.

Ricklefs, M.C. (2007). Sejarah Indonesia Modern. Yogyakarta: Gadjah Mada University Press. 
Subroto, K. (2016). Pengepungan Benteng Portugis: Kekalahan Super Power Portugis oleh Jihad Baabullah di Ternate, di ulasan Lembaga Kajian Syamina, Laporan Khusus, Juli 2016, Edisi 10, Hal. 1-50.

Suryo, D. (2001). Agama dan Perubahan Sosial: Studi tentang hubungan antara Islam, masyarakat, dan struktur sosialpolitik Indonesia. Yogyakarta: LKPSM: Pusat Studi Sosial dan Asia Tenggara Universitas Gadjah Mada.
Utomo, B. B. (2016). Warisan Bahari Indonesia. Jakarta: Yayasan Pustaka Obor Indonesia.

Vlekke, B. H. M. (2008). Nusantara: Sejarah Indonesia. Jakarta: Kepustakaan Populer Gramedia.

Zuhdi, S. dkk. (2002). VOC di Kepulauan Indonesia: Berdagang dan Menjajah. Jakarta: Kedutaan Besar Republik Indonesia, Balai Pustaka. 